\title{
Pożegnanie z Anną Zeidler-Janiszewską
}

Tomasz Majewski 


\section{Pożegnania}

\section{Pożegnanie z Anną Zeidler-Janiszewską}

Tomasz Majewski

TEKSTY DRUGIE 2017, NR 5, S. 330-336

DOI: $10.18318 /$ td.2017.5.22

A nna Zeidler-Janiszewska odeszła dyskretnie i cicho. W sposób, który wielu z nas nie pozwolił na czas się zreflektować i pożegnać. W tym zanikaniu bez śladu, bez zwracania specjalnej uwagi na własne problemy było coś niezmiernie charakterystycznego dla Anki. Kiedy po nagłej wiadomości o Jej śmierci przeglądałem naszą korespondencję z ostatnich paru tygodni, uderzyło mnie, jak bardzo cieszyły ją wieści najzupełniej prywatne i błahe, pozwalające jednak czuć, że jest blisko codziennych spraw. Rozpytywałem ją o podjęte na nowo prace pisarskie, o czytane ostatnio książki, ona pytała mnie raczej o plany urlopowe i komentowała nader trzeźwo nowiny polityczne. Pytała o wspólnych znajomych oraz potwierdzała z radością otrzymanie świeżo wydanej książki. Opisywałem jej odnowiony staraniem Fundacji Borussia żydowski Dom Przedpogrzebowy projektu Ericha Mendelsohna w Olsztynie - Ance wymknęło się, że bardzo

1 Tekst jest rozbudowaną wersją wspomnienia o prof. Annie Zeidler-Janiszewskiej opublikowanego w „Przeglądzie Kulturoznawczym”.
Tomasz Majewski

- kulturoznawca i filmoznawca. Profesor w Katedrze Antropologii Literatury i Badań Kulturowych WP UJ. Opublikował m.in. Dialektyczne feerie. Szkoła frankfurcka i kultura popularna (2011), red. Rekonfiguracje modernizmu. Nowoczesność i kultura popularna (2009) Memory of the Shoah (2010), Migracje modernizmu. Nowoczesność i uchodźcy (2014). 
żałuje, iż Olsztyn poznała jedynie przelotnie i nie zdąży już tego nigdy nadrobić. Byłem świadomy choroby Anki, ale i tak zostałem zaskoczony. Śmierć Anki przyszła nagle. Zostało mi - już bez odpowiedzi z mojej strony - zdanie z lipca „Pisz jak najczęściej!” oraz pytanie, czy mój syn rozumie, co oznacza zgromadzenie, w którym brał niedawno udział.

Pisała, że ma komputer przy łóżku i wysyłała krótkie komentarze do zdjęć z wojaży i z łódzkich obchodów rewolucji 1905 roku na potwierdzenie, że chce je nadal otrzymywać. Był to sposób na intensyfikację komunikacji, której lakoniczność, wymuszona ostatnio chorobą, wyrażała zarówno poczucie kurczenia się czasu, o czym wprost nie mówiła, jak i wyraźny u niej głód życia. Nie chciała po prostu „zapaść się” w ciszę, jak to się czasem zdarzało, była stale obecna, po dwie, trzy wiadomości dziennie w skrzynce, tylko trochę poza sferą grawitacji spraw, które nas - jej interlokutorów - wciągały mocniej, bez opamiętania. Nie pozwala nam zaprzątać sobą głowy. Bezpośrednie pytanie o zdrowie, jeśli już się wymknęło, zbywała krótkimi słowy, niczym wzruszeniem ramion. Odchodziła, ale nie chciała sprawiać wrażenia, że się na to starannie przygotuje. Zbywanie cudzych obaw nie było u niej po prostu stoickie, choć „kruchość” ciała, na którą z konieczności „zaczęła niedawno zwracać uwagę", znosiła dzielnie. Może powinienem był napisać: była dzielna, ale to nie cała prawda, jeśli rozumieć ją w konwencjonalnym sensie. Anka była doprawdy dzielna, ale potrzebowała ostatnio bardziej ludzi i ich obecności niż zazwyczaj; choć milczała o tym lub deklarowała, że nie chce „tymczasem" niczyich szpitalnych wizyt. W pozornie niefrasobliwym traktowaniu choroby wyrażało się jej podstawowe nastawienie etyczne, ale nie emocje. Te ostatnie, jeśli się pojawiały, to chwytały za gardło, zaraz potem skrywane, bo nie były przecież „umyślnymi” wysłanymi przez świadomość, by objaśnić jej życie wewnętrzne.

W ostatnich dniach zastanawiałem się po wiele razy, dlaczego tak trudno jest mi uchwycić osobowość Anki i jej niezwykłe znaczenie dla środowiska akademickiego. Czemu świadectwa tekstowe, jakie nam pozostawiła, nie dźwigną raczej zadania poświadczenia jej inspirującej roli? Myślę, że jest w tym bardzo ważne dla kulturoznawczego środowiska przesłanie. Biofilia Anki otwierająca drzwi zawsze „słabszej”, bo rodzącej się dopiero myśli uczniów, była u niej dużo silniejsza niż „epistemofilia” i potrzeba utrwalenia tekstowego samej siebie, wznoszenia sobie pomnika za sprawą naukowego opus. Ulotne „fenomeny powierzchni” bardziej były dla niej godne namysłu niż oderwany teoretyczny dyskurs, który - jak mawiała - „starzeje się szybciej, niż nasze doświadczenie". Nie oznacza to, że nie pilnowała akademickich 
standardów i nie ceniła dobrego humanistycznego wykształcenia, związanego z wszechstronnym oczytaniem, przeciwnie - widząc dobrą naukową robotę, potrafiła wiele swoim oponentom wybaczyć. Nie potrafię powtórzyć fundamentalnych dla niej tez ani wykazać dalekosiężnych efektów polityki naukowej. Mogę jednak zaświadczyć, że była zaangażowana w niepoliczoną ilość projektów edytorskich, sympozjów i konferencji, spotkań, rozmów przy papierosie, telefonicznych pogawędek, podrzucanych chyłkiem idei, recenzji wydawniczych i habilitacyjnych, krzyżowych wymian telefonów i maili między ludźmi różnych generacji i kręgów, którzy bez jej pośrednictwa prawdopodobnie by się ze sobą nie spotkali, nie zwrócili nawzajem uwagi na publikacje w niszowych periodykach.

Anka była osobą-instytucją, która sieciowała środowisko humanistyczne w stopniu większym niż którakolwiek ze znanych mi osób. Wiedziała jako pierwsza o małej gdańskiej inicjatywie wydawniczej, o ostatniej wystawie w Orońsku, o ciekawym seminarium w Lublinie i mało nagłośnionej wrocławskiej konferencji, na którą polecała „koniecznie się zgłosić". Była dobrze poinformowana o najświeższych habilitacjach w Poznaniu i Łodzi. Nigdy wyłącznie „warszawskocentryczna”, nigdy zorientowana jedynie na własny tylko ośrodek naukowy, na jedną filozofię lub naukową dyscyplinę - jak to się wielu z nas zdarza. Lubiła być na bieżąco, a wychwycenie zasadniczych dla rozmówcy „istotności interpretacyjnych” zajmowało ją, albo przez dobre wychowanie takie chciała sprawiać wrażenie. Wsłuchiwała się w cudze myślenie i szybko orientowała się, kto czym ostatnio „przesiąknął”, kto z lektury jakich prac odniesie akurat teraz największą korzyść.

Ceniła autorów wszechstronnych, antydogmatycznych i takich suflowała w rozmowach - nigdy wprost - studentom i doktorantom jako lektury pożyteczne. Jak pamiętam z początków minionej dekady, spotykało się to na ogół z niezrozumieniem, ponieważ w pewnym wieku szuka się autorów wyrazistych i lektur porządkujących nadmiar idei - a wszystko to leżało na antypodach tego, co faktycznie oferowała Anka w dygresjach rozpiętych między Lyotardem, Flusserem Sprawozdaniem dla Akademii Kafki a Miłośnikiem wulkanów Susan Sontag. We wstępach do kolejnych tomów z serii „Terminusa" ujawniała szczególną predylekcję do Leppenisa, Welscha - którego wraz z Romanem Kubickim przetłumaczyła - i Otto Marquarda deklarującego się jako „tradycjonalista nowoczesności” w jej klasycznym, mieszczańskim sensie. Wiele czasu i uwagi poświęciła zawiązaniu pozrywanych po 1968 roku nici komunikacji między Zygmuntem Baumanem a polską humanistyką. Ceniła krótkie teksty Simmla i nieprzypadkowo własną monografię Między 
melancholią a żałobą zamknęła, pisząc o diagnozie jego ucznia, Kracauera. To, że z większym przekonaniem chwaliła mnie za tekst o vis comica Mela Brooksa i składający hołd egzystencji „drobiazg o nudzie” niż za szerzej zakrojone teoretyczne studia, dobrze łączy mi się z jej uwagą, że gdy ma się już za sobą oczytanie, to "metodologia daje czasem mniej niż bystre oko".

Miałem okazję - nie tylko w związku z pracami redakcyjnymi - przyglądać się, jak u Anki swobodne myślenie krzyżowało się z czymś, co chciałbym nazwać etyką dyskursu. Po pierwsze, nie uważała za konieczne pisać od początku do końca wszystkiego, co na dany temat wiedziała bądź sądziła. Dobitność sądu może być bowiem użyteczna w publicznej polemice, ale dla analizowanej cudzej myśli wiąże się często z „krzywdą" jednostronności "mocnego odczytania" i przesłonięciem potencjalnie ciekawszych znaczeń drugiego planu. Anka miała na uwadze formę lektury, która pozwoliłaby na „odpragmatyzowanie" tekstu, ujawniając po drodze mniejszą użyteczność utartej już hierarchii sensów od wyników egzegezy podejmującej wątki peryferyjne i zaniedbane. Interpretowanie było dla niej przede wszystkim procesem przepracowywania światopoglądowych różnic, które uchodziły z początku za fundamentalne, „nieprzekraczalne”, a ostatecznie okazywały się w większym stopniu problemem z porządku pojęciowego „przekładu” lub efektem absolutyzacji jednej wypowiedzi i ignorowania przez egzegetów innej. W ten sposób broniła siebie i swojego czytelnika przed hibernacją, ,zamrożeniem" sensu i przekształcenia własnego odczytania w formę doktryny. To sprawiało, że nie czuliśmy się chyba, a z pewnością nie czułem się ja jako jej rozmówca, szczególne „zobowiązany” jej wykładniami, co nie stanowiło w dialogu z Anką problemu. Mając inny temperament, argumentowałem z początku mocno, zawczasu próbując "przyszpilić” to, co uznawałem za niejasność lub sprzeczność u czytanego autora. A wtedy słyszałem od niej „a więc tak to widzisz...", co dawało dyskusji nowy wiatr w żagle, gdyż rozwijała się naraz przed naszymi oczyma mapa z obrysami nieoczekiwanych „białych plam" między - terytoriów do dalszego eksplorowania.

Taka etyka dyskursu miała jednak ograniczenie, które w temacie związków nowoczesności i żydowskiej Zagłady umiała wydobyć, cytując Waltera Benjamina z Ulicyjednokierunkowej, piszącego, że ,istnieje tylko jedna granica cierpienia jednostki i wspólnoty, poza którą nic już być nie może: unicestwienie”. Skoro Zagłada oznacza „wstrząśnięcie gmachem całej tradycji filozoficznej" - w czym Anka spotykała się z Zygmuntem Baumanem - to nie pozostawiono nam nienaruszonych pojęć, których moglibyśmy ponownie użyć do racjonalnej organizacji świata, mimo naszego przywiązania do nowoczesnego 
projektu. Nie wszystko można „do dna” zinterpretować, nie chodzi jednak w takim postawieniu sprawy o „tabu” (którego imperatywom należałoby się przeciwstawić), ale - jak mówiła, o „etykę taktu”. O czym nie możemy mówić... po tym wolno nam płakać. I w tym była bliska formacji, którą nazywam "moderną po przejściach", wybierając w pisanych tekstach dużo częściej perspektywę „żałoby po nowoczesności” niż afirmacji „bezwolnego poruszania się w kulturze zgodne z zasadą [...] anything goes", co kojarzyć możemy z konsumpcyjno-karnawałowym wcieleniem „postmoderny”.

Dlatego zapewne cytowała z nieukrywaną aprobatą Kracauera, wyławiając zeń myśl egzystencjalnie sobie bliską: „świat, w którym żyjemy, jest zasłany gruzami - mimo wszelkich prób nowych syntez. Nie ma w tym świecie żadnych całości; składa się z okruchów przypadkowych zdarzeń, których strumień ma nam zastąpić znaczące kontinuum istnienia. Toteż analogicznie trzeba przyjąć, że świadomość jednostki składa się ze strzępów wierzeń i śladów różnych wpływów. Skoro zaś życie wewnętrzne jest pozbawione struktury, w jego luki mogą wdzierać się impulsy z regionów psychosomatycznych. Zdezintegrowane jednostki grają swe życiowe role w zdezintegrowanej rzeczywistości". Interpretując ten ustęp, pisała, że w zgłębianiu pozostałej nam po rozpadzie uniwersum symbolicznego resztki „rzeczywistości w naszym zasięgu” oraz w „zwrocie ku codzienności” widzieć należy lepsze strony obecnej sytuacji kulturowej „aktywnego oczekiwania”. Jej na ogół pesymistyczna diagnoza współczesnej kultury nie była jednak pokrewna konserwatywnej historiozofii upadku. Komentując Steinera, pisała, że chociaż między kulturowym „zanikaniem jednostki” a dzisiejszą „utratą dyspozycji do lektury” (którą to umiejętność sama ceniła) istnieje rzeczywiście bliska korelacja, to raczej nie Steiner, a Kracauer „realistycznie ocenia utratę znaczenia kultury słowa drukowanego" i słusznie „lokuje swe nadzieje w obrazach wytwarzanych technicznie, jak gdyby przebolał proces określony mianem zmierzchu galaktyki Gutenberga”. "Aktywne oczekiwanie” wplecione w proces żałoby, ustępujące powoli poczucie „bycia obolałym” strzeże nas przed pochopnymi „próbami nowych syntez" światopoglądowych, zdecydowanie jeszcze przedwczesnych, dopóki nie przemyślimy powodów dla których rozpadły się syntezy stare.

Opowiadanie się w praktyce pisarskiej po stronie mikrologii, fragmentu, rozumianych jako sposób na kontynuowanie myślenia jednostki w epoce światopoglądów „niewspółmiernych" szło u niej w parze z przekonaniem, że współczesny człowiek „dotyka rzeczywistości jedynie czubkami palców”. Na to, czy tak jest naprawdę, czy nie, wskazuje jednak ostatecznie nie filozoficzny argument, a aksjologiczna a być może również i „teologiczna” wrażliwość 
(której figurą jest „heretycka” optyka apokatastazy). Sceptycyzm wobec roszczeń do finalizacji każdej istotnej dla nas rozmowy przez dyskursywny argument to przecież u podstawy stanowisko „przedteoretyczne” przekute, jak przypuszczam, u Anki także w "metateoretyczne" uzasadnienie dla wypieranych obecnie waloryzacyjnych i światopoglądowych komponentów kulturoznawstwa.

Symboliczno-światopoglądowa sfera kultury nie miała w jej oczach deklarowanej autonomii względem sfery praktyk społecznych, choć aprobatywnie odnosiła się do wywodzącego się ze „szkoły Rittera” Otto Marquarda, piszącego, że sztuka kompensuje „eschatologiczną utratę świata”, stwarzając możliwość zawieszenia „codziennych, nowoczesnych obciążeń". Innymi słowy - tak przynajmniej z rozmów z nią rozumiałem - sceptycyzm i niespieszność humanistyki idącej tropem nowoczesnej sztuki - jej anachronizm jest także wartością wobec niwelującego "przyśpieszenia" modernizacji w innych podsystemach społecznych. Wydaje mi się, że pojęcie sztuki wypracowane we wczesnej fazie nowoczesności ogniskowało się dla niej wokół tego, co dotyczy sfery symboliczno-światopoglądowej, włączając tu kwestię stopniowej utraty jej „samowystarczalności” i specyfiki wobec sfery technicznej i użytkowej. To była - w mikrologicznym skrócie - jej właściwa, choć nie rozwijana teoria kultury, która chyba właśnie estetykę, znajdującą się od dawna także poza terytorium filozofii sztuki, uważała za podstawowy metadyskurs zdający sprawozdanie z przemian doświadczenia nowoczesności.

Choćby nie tak dawno Anka zgadzała się i znowu nie zgadzała z diagnozą Hegla o „zmierzchu sztuki” (powołując się przy tym na bliżej mi nieznane „lewicowe austriackie odczytania Lukácsa oraz Benjamina"), konstatując po długiej pauzie, że formy sztuki leżą poza obrębem „prawdziwych, ostatecznych celów życia", ale i tak dyskursom krytycznym pozwalają przedmiot ich refleksji sobie „unaocznić”, a tym samym go „doświadczać”. György Lukács - przywołany przez Ankę w czasie telefonicznych rozmów - powiązał tematycznie jeden z naszych najdawniejszych i całkiem ostatnich dialogów, w którym Anka wyznała, że lektura Teorii powieści Lukácsa i przedstawiona tam formuła nowoczesnej sztuki jako artykulacji doświadczenia „transcendentalnej bezdomności" była dla niej podczas polonistycznych studiów w Poznaniu „pierwszym filozoficznym przebudzeniem”. Dlatego poczułem silny rezonans, gdy w tamtej ostatniej rozmowie rzuciła zachrypniętym, mocno zmienionym głosem: „A wiesz... Agnes Heller pisała, że w Budapeszcie usuwają pomnik Lukácsa...”. Signum temporis. 


\section{Abstract}

\section{Tomasz Majewski}

JAGIELLONIAN UNIVERSITY (CRACOW)

A Farewell to Anna Zeidler-Janiszewska

Majewski presents a portrait of Anna Zeidler-Janiszewska, professor of cultural studies and philosophy, who passed away in July 2017. Zeidler-Janiszewska worked at the Adam Mickiewicz University in Poznań, the University of Łódź and the University of Social Sciences and Humanities in Warsaw. Her monographs include Sztuka, mit, hermeneutyka (Art, Myth, Hermeneutics, 1988) and Między melancholia a żałobq: Estetyka wobec przemian kultury współczesnej (Between Melancholy and Mourning: Aesthetics and the Transformations of Contemporary Culture, 1996). With Roman Kubicki she published two volumes of interviews with Zygmunt Bauman: Humanista w ponowoczesnym świecie (A Humanist in the Postmodern World, 1997) and Życie w kontekstach (Life in Contexts, 2007).

\section{Keywords}

Anna Zeidler-Janiszewska 